\title{
Antioxidant enzyme activity and lipid peroxidation in rat liver exposed to celecoxib and lansoprazole under epinephrine-induced
}

\section{stress}

\author{
Bohdan Melekh ${ }^{1,2}$, Iryna Ilkiv ${ }^{3}$, Andrii Lozynskyi ${ }^{4 *}$, Alexander Sklyarov $^{3}$ \\ ${ }^{1}$ Department of Pathophisiology, Danylo Halytsky Lviv National Medical University, 69 Pekarska, Lviv, 79010, Ukraine. \\ ${ }^{2}$ St. Mary's Hospital, 6-8Marienstraße, Vechta, 49377, Germany. \\ ${ }^{3}$ Department of Biochemistry, Danylo Halytsky Lviv National Medical University, 69 Pekarska, Lviv, 79010, Ukraine. \\ ${ }^{4}$ Department of Pharmaceutical, Organic and Bioorganic Chemistry, Danylo Halytsky Lviv National Medical University, 69 Pekarska, Lviv, Ukraine.
}

\begin{tabular}{|c|c|}
\hline ARTICLE INFO & ABSTRACT \\
\hline Article history: & \multirow{6}{*}{$\begin{array}{l}\text { The effect of exposure of celecoxib and lansoprazole on antioxidant enzymes and lipid peroxidation has been } \\
\text { studied in liver of rats. We considered the content of malondialdehyde (MDA), and activity of superoxide } \\
\text { dismutase (SOD), catalase (CAT), glutathione peroxidase (GPx), and glutathione reductase (GR). MDA content } \\
\text { was significantly decreased for } 35 \% \text { in rats treated with celecoxib and for } 72 \% \text { in combination with } \\
\text { lansoprazole. The increase of SOD activity after administration of celecoxib in the liver was } 29 \% \text { and observed } \\
\text { decrease of CAT (12\%), GPx (5\%) and GR (33\%) activities. Similarly, an increase in the antioxidant enzymes } \\
\text { was found after administration of celecoxib and lansoprazole such as increase of SOD activity ( } 44 \%) \text { and } \\
\text { decrease of CAT (16\%), GPx (9\%) and GR activities ( } 46 \%) \text {. The current study shows that exposure of celecoxib } \\
\text { and lansoprazole increases the endogenous antioxidant defense system and decreases the lipid peroxidation in } \\
\text { rat liver tissues under epinephrine-induced stress and confirms the important role of these drugs in the reduction } \\
\text { of stress-induced cellular toxicity. }\end{array}$} \\
\hline Received on: 22/02/2017 & \\
\hline Accepted on: 2 & \\
\hline Available online: $30 / 10 / 2017$ & \\
\hline Key words: & \\
\hline $\begin{array}{l}\text { Celecoxib, lansoprazole, } \\
\text { oxidative stress, liver. }\end{array}$ & \\
\hline
\end{tabular}

\section{INTRODUCTION}

In a healthy human body an effective balance exists between the antioxidant and prooxidant system and the ability of cells to protect themselves from oxidant damage. Disruption of this balance has been attributed to several factors including age, genetics, diet, individual behavior, stress and external stressors (Bagchi et al., 1998; Söderholm and Perdue, 2001). It has been also considered that the lipid peroxidation damage is involving in aging and pathological disorders. Some phases of ulcerative colitis, atherosclerosis, neuronal ceroid lipofuscinosis, Alzheimer's disease, liver injury and oxygen toxicity have been discussed in relation to lipid peroxidation (İnal et al., 2001). On the other hand, lipid peroxidation in cells and tissues plays an

\footnotetext{
* Corresponding Author

E-mail: lozisnskij @i.ua (Andrii Lozynskyi)
}

important role in the biosynthesis of prostaglandin and in the mechanisms of immune response especially during peroxynitrite, glutathionyl and protein-tyrosyl radicals derived from macrophages (de Menezes and Augusto, 2001; Costantini and Møller, 2009).

In addition, it has been proposed that lipid peroxidation and antioxidant enzyme activity play a key role in inflammation development (Wiseman and Halliwell, 1996). Thus, the inflammatory process activates a series of receptors and transcription factors such as c-Jun amino terminal kinase, toll-like receptors, nuclear factor-B and the receptor for advanced glycation end products, which lead to $\beta$-cell dysfunction and apoptosis (Goldberg, 2009). In addition, the inflammation involved in the releasing of chemokines such as macrophage migration inhibition factor (MIF), monocyte chemoattractant protein (MCP)-1 and others from stressed tissues. 
Moreover, this mediators released by stressed cells have effects on proinflammatory gene activation and chemokineinduced proliferation producing cytokines such interferon- $\gamma$, TNF$\alpha$, IL-1, IL-6, IL-18, and others. The underlying factors that stimulate expression of these genes include oxidized lipids, reactive oxygen species (ROS), reactive nitrogen species (RNS) and advanced glycation end products (AGEs) (Goldberg, 2009).

Wide spread problems, such as wounds, menstrual pain and inflammation, are nowadays treated by non-steroidal antiinflammatory drugs (NSAIDS) which inhibit the activity of cyclooxygenases (Luong, 1996). However, the non-steroidal antiinflammatory drug (NSAID) therapy in treatment of various diseases has great benefits, but these benefits are offset by the occurrence of potentially complications related to NSAID-induced gastrointestinal injury (Graham et al., 2005). Thus, the traditional NSAIDs such acetylsalicylic acid, indomethacin and ketoprofen inhibiting both cyclooxygenase isoenzymes (COX-1 and COX-2) in the gastrointestinal tract and reduce the intrinsic ability of the gastric mucosa to resist injury induced by endogenous and exogenous agents (Fiorucci et al., 2005). The identification and characterization of the COX-2 enzyme inhibitors which are considered from experimental models supporting the concept that selective COX-2 inhibitors spare the gastrointestinal tract. Thus, these new generation of drugs have been shown to be effective in reducing inflammation while causing significantly less gastrointestinal damage than standard NSAIDs (Reuter et al., 1996; Ilkiv et al., 2007). Released in 1998, celecoxib was the first specific inhibitor of COX-2 available for clinical use. In the treatment of patients with arthritis, pain, menstrual cramps, and colonic polyps, therapeutic doses of celecoxib have proven to be equi-efficacious when compared with other traditional NSAIDs. For patients with rheumatoid arthritis and heart failure, celecoxib is one of the most commonly prescribed drugs in the U.S. (Davies et al., 2000). It should be noted that the action of COX-2-selective NSAIDs are similar to that of a non-selective NSAID plus a proton-pump inhibitor for patients at high risk for ulcer complications. Lansoprazole is one example of a proton pump inhibitor that is effective for treating various acid-related diseases and shows greater efficacy than histamine- 2 receptor antagonists in terms of complete symptom resolution and ulcer healings.

Also not only using different non-steroidal antiinflammatory drugs, but emotional stress and external stressors lead to gastrointestinal damage. Therefore, stress models such as epinephrine-induced is widely used to induce gastric mucosal lesions in animals. Thus, this model reproduce systemic and local consequences of stress exposure to the upper gastrointestinal (GI) tract, resulting in the formation of bleeding gastric lesions and a decrease in mucosal microcirculation. These effects could be caused by gastric constriction of the blood vessels, leading to hypoxia, ischemia, oxidative stress and thereby leading to formation of gastric injury (Fomenko et al., 2014). In addition, the epinephrine administration caused in liver tissues the changes between pro-oxidant production and antioxidant defence system in response to hepatic oxidative stress (Polavarapu et al., 1998). In view of these considerations, the aim of the present study was to evaluate if acute epinephrine-induced stress model in rats modifies the antioxidant defense system and induces LPO in liver in the presence of celecoxib as selective COX-2 inhibitor and lansoprazole as proton-pump inhibitor, in order to determine the involvement of ROS formation on epinephrine-induced stress. To this end, GSH-Px, GR, SOD and CAT activities, as well as MDA levels, as measurement of LPO, were measured in liver homogenates from rats treated with $\mathrm{COX}-2$ and proton-pump inhibitors under epinephrine-induced stress.

\section{MATERIAL AND METHODS}

\section{Animals}

All experiments were carried out using male albino rats weighing 180-220 $\mathrm{g}$ in accordance with the norms of the European Convention for the Protection of Vertebrate Animals Used for Experimental and Other Scientific Purposes (1986), as well as the Ethical Committee of Lviv National Medical University. The rats were fed standard chow and water ad libitum, and were housed in room with controlled temperature $\left(22 \pm 1{ }^{\circ} \mathrm{C}\right)$, humidity $(65-70 \%)$ and light cycle ( $12 \mathrm{~h}$ light/dark). The rats were deprived of food for $18 \mathrm{~h}$ before the experiment, but had free access to water. Six rats were used in each group.

\section{Study protocol}

The study comprised of the following series of experiments: 1) intact animals were used as controls; 2) epinephrine-induced stress in rats were induced by intraperitoneally injection of epinephrine in dose of $2 \mathrm{mg} / \mathrm{kg}$ daily during 5 days (Martinez-Augustin et al., 2000); 3) selective COX2 inhibitor, celecoxib (Pfizer, USA) was introduced in a dose of 10 $\mathrm{mg} / \mathrm{kg}$ in rats on the background of epinephrine-induced stress during two weeks $(n=6) ; 4)$ experimental group, animals received lansoprazole (Pharma Life, Ukraine) in dose $30 \mathrm{mg} / \mathrm{kg}$ intragastrically (via an orally introduced polyethylene tube) once daily per $30 \mathrm{~min}$ after administration celecoxib $(10 \mathrm{mg} / \mathrm{kg})$ on the background of epinephrine-induced stress during two weeks ( $\mathrm{n}=$ 6). Under general anesthesia, rats were sacrificed by decapitation and immediately subjected to necropsy. Livers were quickly removed, immediately washing out the blood with ice-cold $0.9 \%$ saline solution, weighted and stored at $-70^{\circ} \mathrm{C}$. Homogenates of the tissues were prepared as $1.0 \mathrm{~g} / 10 \mathrm{~mL}$ in $250 \mathrm{mM}$ sucrose, $1 \mathrm{mM}$ EDTA, $1 \mathrm{mM}$ DL-dithiothreitol and $15 \mathrm{mM}$ Tris $\mathrm{HCl}(\mathrm{pH}$ 7.4), using HS-30E homogenizer (WiseStir, Republic of Korea). Each homogenate was centrifuged for $30 \mathrm{~min}$ at $800 \mathrm{~g}$. The resulting supernatant fraction was used to determine enzyme activities and MDA levels. The protein concentrations of the supernatant were determined by the method described by Bradford (1976).

\section{Enzyme activities}

SOD activity was measured using quercetin as the substrate after suitable dilution method as described by Kostyuk $e t$ al. (1990). The assay mixture in a total volume of $1 \mathrm{~mL}$ consisted 
$0.1 \mathrm{~mol} / \mathrm{L}$ sodium phosphate buffer $(\mathrm{pH} 7.8)$ and $0.08 \mathrm{mmol} / \mathrm{L}$ EDTA at a $1: 1$ proportion. The $0.1 \mathrm{~mL}$ of tissue sample (1:1000) after dilution was added to $2.3 \mathrm{~mL}$ of distilled water, after which 1 $\mathrm{mL}$ of assay mixture with EDTA and sodium phosphate buffer. The increase in absorbance due to oxidation of quercetin at 0 and $20 \mathrm{~min}$ was measured spectrophotometrically at $406 \mathrm{~nm}$. In the blank, tissue sample was substituted by equal quantities of distilled water. One unit of SOD activity is defined as the quantity of enzyme that inhibited quercetin oxidation by $50 \%$ under given experimental conditions.

CAT activity was assayed according to the method of Korolyuk et al. (1988). The reaction was started by the addition of $0.1 \mathrm{~mL}$ of tissue sample to $1 \mathrm{~mL}$ of $4 \%$ ammonium molybdate and $2 \mathrm{~mL}$ of $0.03 \% \mathrm{H}_{2} \mathrm{O}_{2}$ solution. One unit of catalase activity is defined as the amount of enzyme required to clear $1 \mu \mathrm{mol}$ of $\mathrm{H}_{2} \mathrm{O}_{2}$ per minute per gram of tissue. The breakdown of hydrogen peroxide in the reaction mixture was measured spectrophotometrically at $410 \mathrm{~nm}$.

The activity of GPx in the tissue homogenates was measured spectrophotometrically as described by Moin (1986). The assay mixture contained $0.8 \mathrm{~mL}$ of $0.1 \mathrm{~mol} / \mathrm{L}$ Tris- $\mathrm{HCl}$ with $12 \mathrm{mmol} / \mathrm{L}$ sodium aside and $6 \mathrm{mmol} / \mathrm{L}$ EDTA, $\mathrm{pH} 8.9,0.2 \mathrm{~mL}$ of 1:50 or tissue homogenates, $0.1 \mathrm{~mL}$ of $0.01 \mathrm{~mol} / \mathrm{L} \mathrm{5,5-dithiobis-2-}$ nitrobenzoic acid, $1 \mathrm{~mL}$ of $20 \mathrm{mmol} / \mathrm{L}$ t-butylhydroperoxide, and $0.1 \mathrm{~mL}$ of $4.8 \mathrm{mmol} / \mathrm{L} \mathrm{GSH}$. The decrease in the absorbance at $412 \mathrm{~nm}$ was followed spectrophotometrically. GR activity in the tissue homogenates was performed by the method of Glatzle et al. (1974). GR activity was determined spectrophotometrically by measuring NADPH oxidation at $340 \mathrm{~nm}$. The reaction mixture contained tissue samples (0.05-0.2 mg), $0.1 \mathrm{mM}$ NADPH, $0.5 \mathrm{mM}$ EDTA, 0.1 M potassium phosphate (pH 7.5), $200 \mathrm{mM} \mathrm{KCl}$. After 5 min of preincubation $\left(37{ }^{\circ} \mathrm{C}\right)$, the reaction was initiated by addition of $1 \mathrm{mM}$ GSSG.

\section{Measurement of lipid peroxidation levels}

Estimates of lipid peroxidation levels were evaluated by the thiobarbituric acid reactive substances (TBARS) procedure, described by Timirbulatov and Selezniev (1981) on homogenized tissues. This method involves reaction of TBA with the degradation product of lipid peroxidation, MDA, under conditions of high temperature and acidity to generate a colored adduct that is measured spectrophotometrically. Briefly, $2 \mathrm{~mL}$ of distilled water was added to $0.1 \mathrm{~mL}$ of tissue sample, which followed by $1 \mathrm{~mL}$ of TBA reagent and $1 \mathrm{~mL}$ of trichloracetic acid and, and the mixture heated in a boiling water bath for $10 \mathrm{~min}$ before the addition of butanol. After cooling, the mixture was centrifuged for $10 \mathrm{~min}$. Absorbance in the organic phase was determined at $532 \mathrm{~nm}$ and samples were compared to a blank.

\section{Statistical methods}

Each experiment was performed in triplicate and average values were recorded. Results are expressed as the means \pm SD. The data were evaluated statistically using Student's t-test. In general, a value of $\mathrm{p}<0.05$ was regarded to be statistically significant and marked with an asterisk.

\section{RESULTS AND DISCUSSION}

The present study demonstrates that the antioxidant defense systems are modified by celecoxib and lansoprazole administration, altering the activities of antioxidant enzymes, and as a consequence, suggesting the role of ROS in the pathogenesis of stress-induced damage. This is the first study concerning about the changes in the activities of antioxidant enzymes produced by administration of selective COX-2 and proton-pump inhibitors in the liver of rats. Thus, the liver has been described as the important organ involved in the in cellular redox homeostasis, due to the formation of various intracellular antioxidant enzymes responsible for ROS clearance and the function of the key systemic antioxidant agent, GSH/GSSG (Klaassen, 2001). In addition, the liver plays an important role in metabolism of xenobiotics, therefore, its oxidative status might be affected by the administration of various drugs. Our results indicate that most reactive biochemical products that enter the reactions with enzymes are MDA. They consist of reaction products with MDA and occur as finished products of lipoperoxidation. As result, the content of malondialdehyde (MDA) increased 3.5-fold as compared to control rats. The selective COX-2 inhibitor, celecoxib, elicited a decrease of MDA content for $35 \%$ and for $72 \%$ in combination with lansoprazole as compared with indices of stress group (Figure 1).

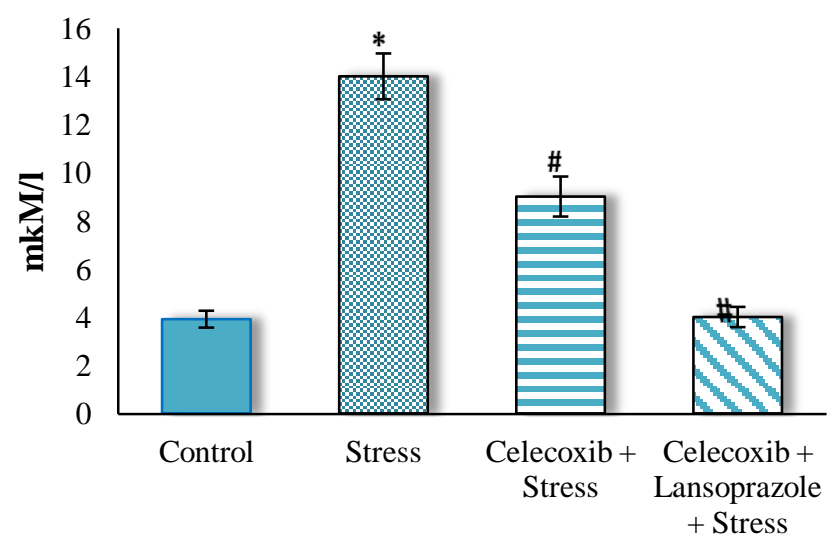

Fig. 1: Effect of celecoxib and lansoprazole (10 and $30 \mathrm{mg} / \mathrm{kg}$ ) on malondialdehyde (MDA) levels under epinephrine-induced stress in rat liver tissues. The results are expressed as mean \pm SD for 6 rats per group; ${ }^{*} \mathrm{p}<0.05$ in comparison of control group; ${ }^{\#} \mathrm{p}<0.05$ versus the indices of stress.

Simultaneously, we found interrelationships between administration of celecoxib and lansoprazole and the activity of the important antioxidant enzymes SOD, CAT, GPx, and GR and TBARS products in the liver of rats. The activities of SOD found in liver from experimental rats are shown in Figure 2. 


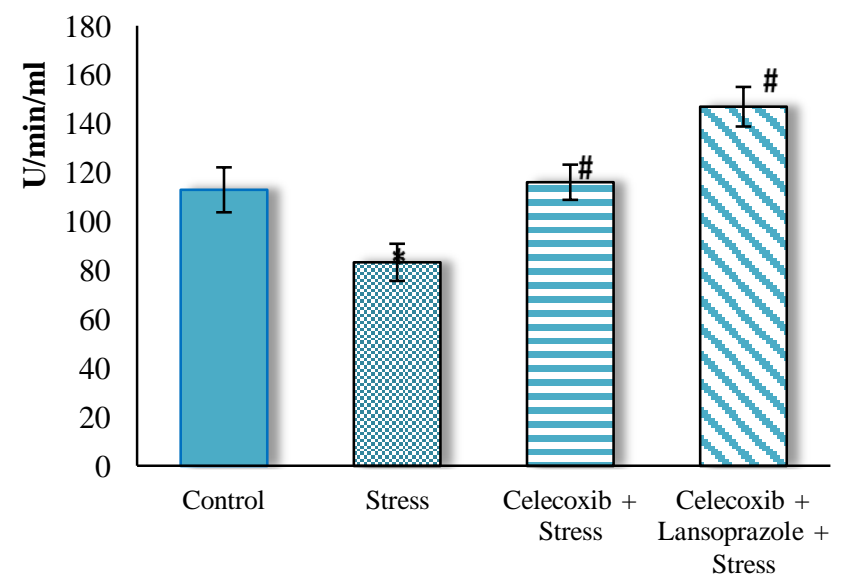

Fig. 2: Effect of celecoxib and lansoprazole (10 and $30 \mathrm{mg} / \mathrm{kg}$ ) on the activity of superoxide dismutase (SOD) under epinephrine-induced stress in rat liver tissues. The results are expressed as mean \pm SD for 6 rats per group; ${ }^{*} \mathrm{p}<0.05$ in comparison of control group; \#p $<0.05$ versus the indices of stress.

The celecoxib administration increased SOD activity for $29 \%(\mathrm{p}<0.01)$ and celecoxib+ lansoprazole for $44 \%(\mathrm{p}<0.01)$ as compared with stress group. The administration of celecoxib decreased in liver catalase activity for $12 \%$. Indices of the catalase activity in celecoxib + lansoprazole pretreated rats subjected to epinephrine-induced stress were similar to those of the group treated with celecoxib (Figure 3 ).

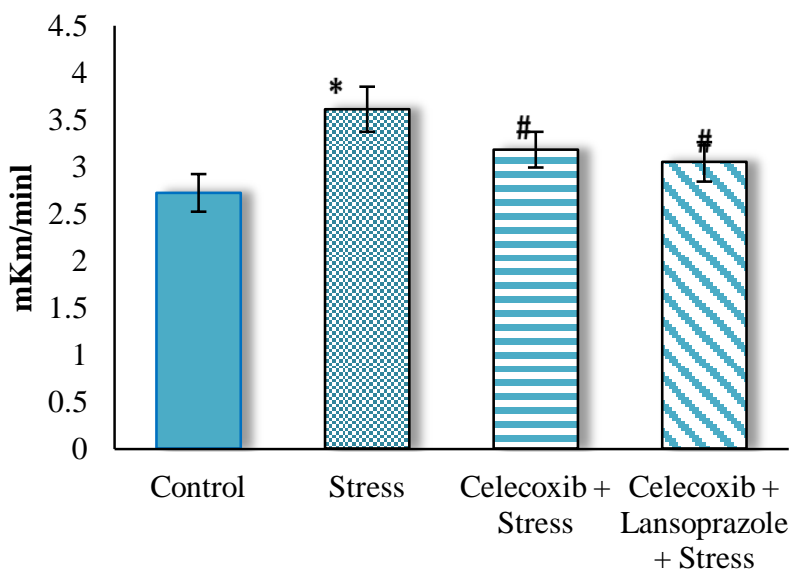

Fig. 3: Effect of celecoxib and lansoprazole (10 and $30 \mathrm{mg} / \mathrm{kg}$ ) on the activity of catalase (CAT) under epinephrine-induced stress in rat liver tissues.

The results are expressed as mean $\pm \mathrm{SD}$ for 6 rats per group; ${ }^{*} \mathrm{p}<0.05$ in comparison of control group; \#p $<0.05$ versus the indices of stress.

Administration of celecoxib under acute epinephrineinduced stress conditions, did not significantly decrease GPx activity. In the liver the percentages of GPx reduction were 5 and
$9 \%$ in rats treated with celecoxib and celecoxib + lansoprazole, respectively, when compared with stress values (Figure 4).

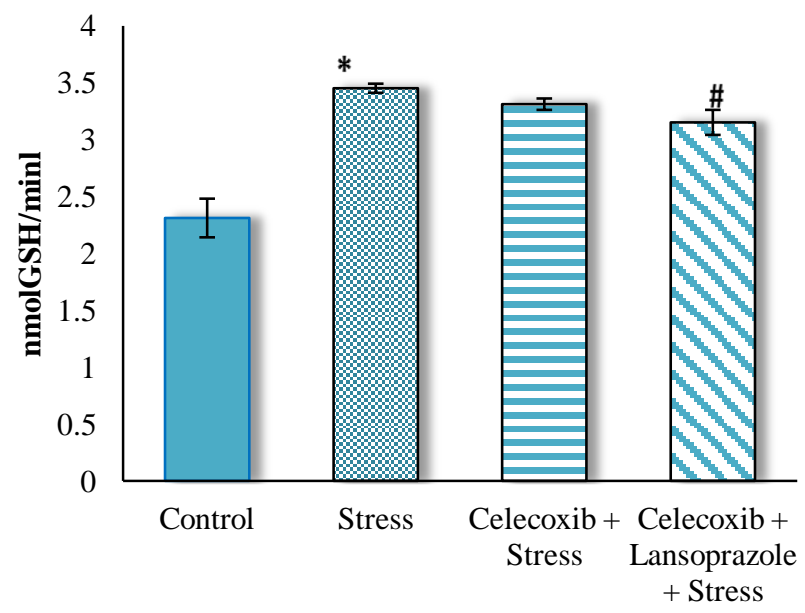

Fig. 4: Effect of celecoxib and lansoprazole (10 and $30 \mathrm{mg} / \mathrm{kg}$ ) on the activity of glutathione peroxidase (GPx) under epinephrine-induced stress in rat liver tissues. The results are expressed as mean \pm SD for 6 rats per group; $* p<0.05$ in comparison of control group; $\# \mathrm{p}<0.05$ versus the indices of stress.

Changes in GR activities, the enzyme involved in generation of GSH from GSSG, are shown in Figure 5. Liver glutathione reductase activity in the rats after administration of celecoxib was about $33 \%$ lower than stress group. In rats after administration celecoxib + lansoprazole liver glutathione reductase also decreased, but to a final value about $12 \%$ higher than that in intact rats.

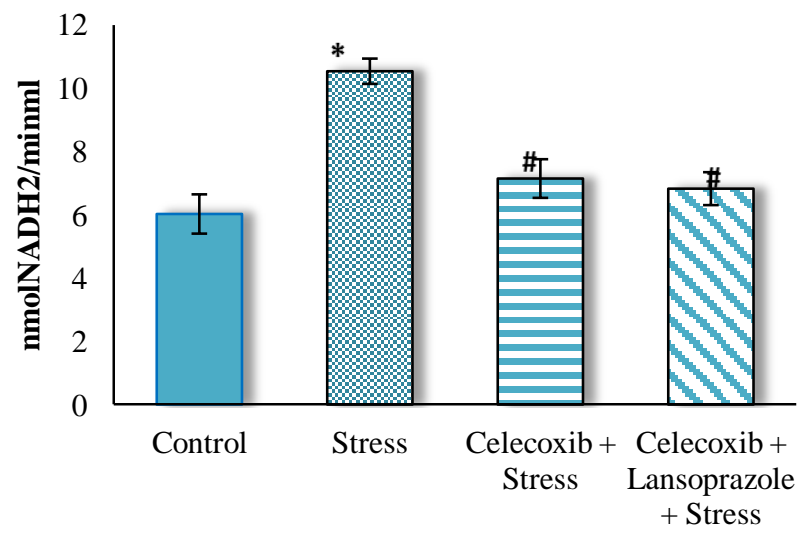

Fig. 5: Effect of celecoxib and lansoprazole (10 and $30 \mathrm{mg} / \mathrm{kg}$ ) on the activity of glutathione reductase (GR) under epinephrine-induced stress in rat liver tissues. The results are expressed as mean \pm SD for 6 rats per group; ${ }^{*} p<0.05$ in comparison of control group; \#p<0.05 versus the indices of stress.

Our results show an increase of activity of SOD and decrease the activities of CAT GPx, GR in liver of rats administrated with selective COX-2 and proton-pump inhibitors when compared to stress group. These results suggest decreased 
production of oxygen free radicals by celecoxib and lansoprazole. The endogenous scavenger, SOD, which removes the superoxide anion radicals by converting them into hydrogen peroxide $\left(\mathrm{H}_{2} \mathrm{O}_{2}\right)$ and $\mathrm{O}_{2}$, was significantly increased in the two experimental groups. The observed increase in liver SOD enzyme activity after administration of the tested drugs may be a consequence of oxidative activation of enzyme protein or increased of their synthesis. Therefore, the increase in the activity of SOD in liver tissues of celecoxib and lansoprazole treated rats might indicate a reduce accumulation of superoxide anion radical with oxidative stress, contributing decrease liver toxicity (Zelko et al., 2002). In addition, SOD enzymes in human cells work in conjunction with $\mathrm{H}_{2} \mathrm{O}_{2}$-removing enzymes such as CAT and GPx. Thus, the relative contributions of CAT and GPx, in decomposition of endogenously produced hydrogen peroxide, follow tissue specificity, especially in liver and renal tissues (Kaushik and Kaur, 2003). The decreased activities of GPx and CAT in liver tissues of the treated rats indicate the highly reduced capacity to scavenge hydrogen peroxide produced in these tissues, with an the reduction of oxidative stress and generation of ROS in response to administration of selective COX-2 and proton-pump inhibitors (Escobar et al., 1996). The observed decrease in glutathione reductase activities after administration of celecoxib and lansoprazole indicates a decrease in the conversion of oxidized glutathione (GSSG) back to its reduced form (GSH), which indicate further reduction of ROS during oxidative challenge (Circu and Aw, 2010). In addition, the changes in glutathione reductase activities follow qualitatively a similar pattern to those of follow qualitatively a similar pattern to those of lipogenesis and of several enzymes involved in lipid biosynthesis, resulting the decrease of MDA levels and cellular free radical stress (Knapen et al., 1999).

\section{CONCLUSION}

Our results support the hypothesis that enzymatic free radical defense systems can be impaired in epinephrine-induced stress rats and that the resultant enhanced oxidative stress can contribute to pathological liver injury. However, the exposure of celecoxib and lansoprazole to epinephrine-induced stress results in an increase in the endogenous antioxidant defense system together with an decrement in lipid peroxidation in rat liver tissues, suggesting an important role of these drugs in the pathogenesis of stress-induced cellular toxicity.

\section{Financial support and sponsorship: Nil.}

Conflict of Interests: There are no conflicts of interest.

\section{REFERENCES}

Bagchi D, Carryl OR, Tran MX, Krohn RL, Bagchi DJ, Garg A et al. Stress, diet and alcohol-induced oxidative gastrointestinal mucosal injury in rats and protection by bismuth subsalicylate. J Appl Toxicol, 1998; 18:3-13.
Bradford MM. A rapid and sensitive method for the quantitation of microgram quantities of protein utilizing the principle of protein-dye binding. Anal Biochem, 1976; 72:248-254.

Circu ML, Aw TY. Reactive oxygen species, cellular redox systems, and apoptosis. Free Radic Biol Med, 2010; 48:749-762.

Costantini D, Møller AP. Does immune response cause oxidative stress in birds? A meta-analysis. Comp Biochem Physiol Part A, 2009; 153:339-344.

Davies NM, McLachlan AJ, Day RO, Williams KM. (2000). Clinical pharmacokinetics and pharmacodynamics of celecoxib. Clin Pharmacokinet, 2000; 38:225-242.

Escobar JA, Rubio MA, Lissi EA. SOD and catalase inactivation by singlet oxygen and peroxyl radicals. Free Radic Biol Med, 1996; 20:285-290.

Fiorucci S, Antonelli E, Distrutti E, Rizzo G, Mencarelli A, Orlandi $\mathrm{S}$ et al. Inhibition of hydrogen sulfide generation contributes to gastric injury caused by anti-inflammatory nonsteroidal drugs. Gastroenterol, 2005; 129:1210-1224.

Fomenko I, Sklyarov A, Bondarchuk T, Biletska L, Panasyuk $\mathrm{N}$, Wallace JL. Effects of conventional and hydrogen sulfide-releasing non-steroidal anti-inflammatory drugs in rats with stress-induced and epinephrine-induced gastric damage. Stress, 2014; 17:528-537.

Glatzle D, Vuilleumier JP, Weber F, Decker K. Glutathione reductase test with whole blood, a convenient procedure for the assessment of the riboflavin status in human. Experientia, 1974; 30:665667.

Goldberg RB. Cytokine and cytokine-like inflammation markers, endothelial dysfunction, and imbalanced coagulation in development of diabetes and its complications. J Clin Endocrinol Metab, 2009; 94:3171-3182.

Graham DY, Opekun AR, Willingham FF, Qureshi WA. Visible small-intestinal mucosal injury in chronic NSAID users. Clin Gastroenterol Hepatol, 2005; 3:55-59.

Ilkiv I, Lesyk R, Sklyarov O. Evaluation of novel 4thiazolidinone-based derivatives as possible cytoprotective agents against stress model in rats. J App Pharm Sci, 2017; 7:199-203.

İnal ME, Kanbak G, Sunal E. Antioxidant enzyme activities and malondialdehyde levels related to aging. Clin Chim Acta, 2001; 305:7580 .

Kaushik S, Kaur J. Chronic cold exposure affects the antioxidant defense system in various rat tissues. Clin Chim Acta, 2003; 333:69-77.

Klaassen CD. 2001. Casarett \& Doull's Toxicology. The Basic Science of Poisons. New York, USA: Mc Graw-Hill.

Knapen MFCM, Zusterzeel PL, Peters WH, Steegers EA. Glutathione and glutathione-related enzymes in reproduction: a review. Eur J Obstet Gynecol Reprod Biol, 1999; 82:171-184.

Korolyuk MA, Ivanova LI, Majorova IT. Methods of definition of catalase activity. Lab Manuals, 1988; 1:16-19.

Kostyuk VA, Potapovich AI, Kovaleva JI. Simple and sensitive method of definition of superoxide dismutase, based on reaction of oxidation of kvercetine. Questions Med Chem, 1990; 2:88-91.

Luong C, Miller A, Barnett J, Chow J, Ramesha C, Browner MF. Flexibility of the NSAID binding site in the structure of human cyclooxygenase-2. Nat Struct Mol Biol, 1996; 3:927-933.

Martinez-Augustin O, de Medina FSJr, de Medina FS. Effect of psychogenic stress on gastrointestinal function. J Physiol Biochem, 2000; 56:259-273.

de Menezes SL, Augusto O. EPR detection of glutathionyl and protein-tyrosyl radicals during the interaction of peroxynitrite with macrophages (J774). J Biol Chem, 2001; 276:39879-39884.

Miner P, Katz PO, Chen Y, Sostek M. Gastric acid control with esomeprazole, lansoprazole, omeprazole, pantoprazole, and rabeprazole: a five-way crossover study. Am J Gastroenterol, 2003; 98:2616-2620.

Moin VM. Simple and specific method of measurement of glutathione peroxidase activity in the erythrocytes. Lab Manuals, 1986; 12:724-727. 
Polavarapu R, Spitz DR, Sim JE, Follansbee MH, Oberley LW, Rahemtulla A et al. Increased lipid peroxidation and impaired antioxidant enzyme function is associated with pathological liver injury in experimental alcoholic liver disease in rats fed diets high in corn oil and fish oil. Hepatology, 1998; 27:1317-1323.

Reuter BK, Asfaha S, Buret A, Sharkey KA, Wallace JL. Exacerbation of inflammation-associated colonic injury in rat through inhibition of cyclooxygenase-2. J Clin Invest, 1996; 98:2076-2085.

Söderholm JD, Perdue MH. II. Stress and intestinal barrier function. Am J Physiol Gastrointest Liver Physiol, 2001; 280:G7-G13.

Timirbulatov RA, Selezniev EI. Method for increasing intensity of free radical oxidation of blood lipid containing components and its diagnosis value. Lab Manuals, 1981; 4:209-211.

Wiseman H, Halliwell B. Damage to DNA by reactive oxygen and nitrogen species: role in inflammatory disease and progression to cancer. Biochem J, 1996; 313:17-29.
Zelko IN, Mariani TJ, Folz RJ. Superoxide dismutase multigene family: a comparison of the CuZn-SOD (SOD1), Mn-SOD (SOD2), and EC-SOD (SOD3) gene structures, evolution, and expression. Free Radic Biol Med, 2002; 33:337-349.

\section{How to cite this article:}

Melekh B, Ilkiv I, Lozynskyi A, Sklyarov A. Antioxidant enzyme activity and lipid peroxidation in rat liver exposed to celecoxib and lansoprazole under epinephrine-induced stress. J App Pharm Sci, 2017; 7 (10): 094-099. 